\title{
Pengembangan Bahan Ajar Bahasa Inggris Berbasis Analisis Kebutuhan Dunia Kerja
}

\author{
Putu Shinta Noviaty ${ }^{1}$, Eka Ayu Purnama Lestari ${ }^{2}$, Komang Trisnadewi ${ }^{3}$ \\ ${ }^{12}$ STMIK STIKOM Indonesia \\ ${ }^{3}$ UHN I Gusti Bagus Sugriwa Denpasar
}

\section{Article Info}

Article history:

Received 21 Desember 2021

Publish 01 Januari 2021

\section{Keywords:}

Teaching material development

Need analysis

English teaching material

Information Technology

Material

\section{Info Artikel}

Article history:

Diterima 21 Desember 2021

Publis 01 Januari 2022

\begin{abstract}
Time development will affect the changing needs of graduates. Using teaching materials as one of the factors supporting the learning process is an absolute thing to do so that learning becomes directed. Therefore, it is necessary to conduct this research to prepare highly competitive human resources. This research is a development that aims to produce materials oriented towards analyzing the needs of graduate users. The ADDIE method includes analysis, design, development, implementation, and evaluation. It was chosen as the basis for developing teaching materials for STMIK STIKOM Indonesia students on Information Technology. The analysis stage is the stage carried out to describe what the learner will learn. Next is the design stage. The purpose of learning, strategies, learning resources, tests are designed. It becomes a supporting factor for the learning process. Development is the next stage where the process of making materials is carried out according to a predetermined design. The next stage is implementation. Submission of material by the results of the development is carried out at this stage. The last stage is the evaluation stage. The revision process is carried out at this stage to assess the designed learning program.

Abstrak

Perkembangan zaman tentunya akan berpengaruh pada perubahan kebutuhan lulusan yang wajib diantisipasi oleh perguruan tinggi. Menyiapkan bahan ajar sebagai salah satu faktor pendukung proses pembelajaran adalah hal yang mutlak untuk dilakukan sehingga pembelajaran menjadi terarah. Oleh karena itu sangat penting untuk melakukan penelitian ini demi menyiapkan sumber daya manusia yang berdaya saing tinggi. Penelitian ini merupakan penelitian pengembangan yang bertujuan untuk menghasilkan bahan ajar yang berorientasi pada analisis kebutuhan pengguna lulusan. Metode ADDIE yang mencakup analysis, design, development, implementation dan evaluation dipilih sebagai dasar untuk mengembangkan bahan ajar bahasa Inggris bagi mahasiswa STMIK STIKOM Indonesia pada bidang Teknologi Informasi. Tahapan analysis adalah tahapan yang dilakukan untuk mendeskrpsikan apa yang akan dipelajari oleh pembelajar. Selanjutnya adalah tahapan design. Pada tahapan ini, tujuan dari pembelajaran dirumuskan, strategi pembelajaran ditentukan, sumber belajar dicari, tes dibuat dan mendesain faktor pendukung proses pembelajaran lainnya. Development adalah tahapan selanjutnya dimana dilakukan proses pembuatan bahan ajar sesuai dnegan desain yang telah ditentukan. Tahapan selanjutnya adalah implementasi. Penyampaian materi sesuai dengan hasil pengembangan dilakukan pada tahapan ini. Tahapan yang terakhir adalah tahapan evaluation. Proses revisi dilakukan pada tahapan ini dengan tujuan menilai program pembelajaran yang telah didesain.
\end{abstract}

This is an open access article under the Lisensi Creative Commons AtribusiBerbagiSerupa 4.0 Internasional (c) (1) (-)
Corresponding Author:

Putu Shinta Noviaty

STMIK STIKOM Indonesia

Email: Shintanoviaty@gmail.com 


\section{PENDAHULUAN}

Untuk mendapatkan pekerjaan yang bermutu, kompetensi yang dimiliki juga harus menunjang. Setiap orang berusaha agar mendapatkan pekerjaan yang layak dan mengindari pengangguran. Salah satu jalan yang banyak ditempuh adalah dengan mengeyam pendidikan tinggi di bangku kuliah. Harapannya adalah agar cepat mendapatkan pekerjaan dan pekerjaan yang didaptkan lebih baik. Kenyataannya, tamatan perguruan tinggi juga ada yang menganggur. Terkait pengangguran pada jenjang pendidikan tingggi, diketahui dari data BPS bahwa presentasi pengangguran dari tamatan jenjang pendidikan tinggi semakin meningkat. Tahun 2018 tercatat presentase pengangguran sebesar 0,90\%. Kemudian di tahun 2091 meningkat menjadi 1,58 persen (Dewi, 2019).

Daya saing dunia kerja erat kaitannya dengan kompetensi yang dimiliki. Penguasaan hard skill dan soft skill tidak bisa dipisahkan dari dunia kerja. Menteri Pendidikan dan Kebudyaan, Nadiem Makarim mengatakan bahwa hard skill dan soft skill sama pentingnya dalam dunia Pendidikan. Hard skill diperlukan agar dapat beradaptasi dengan teknologi, sedangkan soft skill diperlukan agar mampu berkreativitas dan berpikir secara kritis (Ihsan, 2020). Hard skill sebagai kemampuan teknis adalah kemampuan yang berkaitan dengan ilmu pengetahuan yang dapat dilihat atau dipraktikkan secara langsung.

Salah satu contoh hard skill adalah kemahiran berbahasa asing. Dari sekian Bahasa asing yang ada, bahasa Inggris menjadi bahasa internasional yang artinya bahasa yang digunakan agar dapat berkomunikasi dengan orang-orang dari seluruh dunia. Bahasa Inggris menjadi tuntutan yang penting dalam menunjang kompetensi di dunia kerja. Lebih lanjut, M. Hanif Dhakiri, mengatakan bahwa kemampuan bahasa asing diperlukan untuk meningkatkan kualitas pekerjaan (Idris, 2018).Berbeda dengan soft skill yang merupakan kemampuan alami yang ada pada diri seseorang, hard skill adalah kemampuan yang dapat dipelajari melalui pendidikan, salah satunya pendidikan formal di kampus.

Dunia pendidikan dan dunia kerja seharusnya berjalan secara selaras agar kompetensi lulusan pada perguruan tinggi dapat sesuai dengan harapan dari pemberi kerja. Proses pembelajaran akan dilalui oleh mahasiswa dalam upaya memperoleh kompetensi tersebut. Salah satu faktor penting dalam proses pembelajaran adalah pemilihan bahan ajar yang sesuai berdasarkan analisis kebutuhan pengguna lulusan sehingga materi yang diberikan berfokus pada kompetensi yang diharapkan dunia kerja sesungguhnya. Pemilihan bahan ajar memang menjadi masalah bagi pengajar dalam membantu pembelajar untuk mencapai kompetensi (Aisyah, Siti; Noviyanti \& Triyanto, 2020). Bahan ajar dapat diartikan sebagai bahan atau materi yang disusun secara sistematis yang digunakan dalam proses pembelajaran oleh guru dan siswa (Purwanto, 2001). Seiring dengan perkembangan zaman, kebutuhan dunia kerja pun juga akan mengalami perkembangan, oleh karena itu penting untuk mengadakan analisis kebutuhan pengguna secara berkala. Penelitian ini ingin mengembangkan bahan ajar mata kuliah bahasa Inggris dengan berdasarkan analisis kebutuhan yang telah dilakukan pada penelitian sebeumnya. Penelitian ini merupakan penelitian pengembangan dan mutlak untuk dilakukan karena dengan pemilihan bahan ajar yang tepat maka lulusan yang dihasilkan diharapkan memiliki kompetensi yang tepat pula.

Berdasarkan latar belakang di atas, adapun rumusan masalah pada penelitian ini adalah Bagaimana pengembangan bahan ajar bahasa Inggris berdasarkan analisis kebutuhan dunia kerja? Masalah yang dibahas pada penelitian ini pengembangan bahan ajar Bahasa Inggris yang meliputi kemampuan berbicara, mendengar, menulis dan membaca dan terfokus pada bidang Teknologi Informasi (TI).

Beberapa penelitian mengenai pengembangan bahan ajar telah dilakukan sebagai berikut. Penelitian pertama dilakukan oleh Lestari (2021). Penelitian tersebut menghasilkan sebuah modul bahasa Inggris berbasis andragogi yang memiliki efek potensial terhadap hasil belajar mahasiswa 
pada Universitas Muhammadiyah Palembang. Model Rowntree digunakan dalam prosedur penelitian yang mencakup perencanaan, pengembangan dan evaluasi. Terdapat beberapa tahapandalam evaluasi, yaitu self evaluation, expert review, one-to-one evaluation, small group evaluation, dan field test (Lestari et al., 2021).

Penelitian berikutnya dilakukan oleh Mudofir (2016). Penelitian tersebut berfokus pada integrase bahasa Inggris dan multimedia. Disampaikan bahwa pengembangan bahan ajar yang berbasis multimedia dapat membuat proses pemeblajaran menjadi menarik dan meningkatkan semangat mahasiswa dalam belajar bahasa Inggris. Adapun langkah-langkah yang dilaukan dalam pengembangan bahan ajar berbasis multimedia adalah menentukan jenis multimedia pembelajaran, menentukan tema materi ajar, menyususn cerita, menggunakan teknik amati modifikasi dan menetapkan target (Mudofir, 2016).

Penelitian selanjutnya dilakukan oleh Hakim, M. Arif Rahman; Kurniawan, Yuda Septian; Saputra, Andri (2019). Penelitian tersebut dilakukan atas permasalahn kesulitan penentuan bahan ajar. Hail dari penelitian tersebut adalah produk bahan ajar English for Specific Purposes (ESP) dengan pendekatan Contextual Teaching \& Learning (CTL) dengan menggunakan modul ASSURE yang mencakup tahapan analisis pembelajaran, penentuan standar dan tujuan, pemilihan strategi,teknologi, media dan bahan ajar, dan evaluasi (Hakim, M. Arif Rahman; Kurniawan, Yuda Septian; Saputra, 2019).

Penelitian ini memiliki kaitan dengan penelitian sebelumnya, namun memiliki perbedaan. Penelitian ini berfokus pada pengembangan bahan ajar untuk English for Specific Purposes bagi mahasiswa Teknologi Informasi yang mana sebelumnya telah dilakukan analisis kebutuhan terhadap pengguna lulusan di dunia kerja. Metode yang akan digunakan adalah ADDIE yang mencakup analysis, design, development, implementation dan evaluation.

\section{METODE PENELITIAN}

Penelitian ini adalah jenis penelitian pengembangan untuk menghasilkan sebuah bahan ajar berdasarkan analisis kebutuhan pengguna lulusan. Penelitian pengembangan dapat diartikan sebagai penelitian yang bertujuan untuk mendapatkan informasi selanjutnya dilakukan pengembangan untuk menghasilkan produk dan mengaji keefektifannya (Sugiyono, 2015). Lulusan yang dimaksud dalam penelitian ini adalah mahasiswa program Teknologi Informasi pada STMIK STIKOM Indonesia.. Produk yang dihasilkandari penelitian ini adalah bahan ajar.

Data penelitian ini adalah data kualitatif yang berupa hasil analisis kebutuhan dunia kerja yang selanjutnya dijadikan dasar penyusunan bahan ajar. Analisis kebutuhan mencakup empat kemampuan berbahasa Inggris, yaitu menyimak, membaca, berbicara dan menulis. Kuesioner disebar kepada sejumlah penyedia tenaga kerja yang memperkerjakan lulusan STMIK STIKOM Indonesia yang bekerja di bidang Teknologi Informasi.

Metode ADDIE digunakan sebagai acuan dalam penelitian ini yang terdiri dari 5 tahapan yaitu analysis, design, development, implementation dan evaluation (Branch, 2009). Tahapan analysis adalah tahapan yang dilakukan untuk mendeskrpsikan apa yang akan dipelajari oleh pembelajar. Selanjutnya adalah tahapan design. Pada tahapan ini, tujuan dari pembelajaran dirumuskan, strategi pembelajaran ditentukan, sumber belajar dicari, tes dibuat dan mendesain faktor pendukung proses pembelajaran lainnya. Development adalah tahapan selanjutnya dimana dilakukan proses pembuatan bahan ajar sesuai dengan desain yang telah ditentukan. Kegiatan yang dilakukan dapat berupa memproduksi, membeli atapun merevisi bahan ajar. Tahapan selanjutnya adalah implementasi. Penyampaian materi sesuai dengan hasil pengembangan dilakukan pada tahapan ini. Tahapan yang terakhir adalah tahapan evaluation. Proses revisi dilakukan pada tahapan ini dengan tujuan menilai program pembelajaran yang telah didesain. 


\section{HASIL PENELITIAN DAN PEMBAHASAN}

\subsection{Hasil}

Produk yang dihasilkan terdiri dari empat kompetensi bahasa Inggris, yaitu membaca, menulis, berbicara dan mendengarkan. Kompetensi bahasa menjadi acuan pengembangan bahan ajar pada penelitian pengembangan ini yang berfokus pada bidang teknologi informasi. Adapun struktur dari dari masing-masing-masing kompetensi adalah Topic, Description, warm-up, introduction, presentation, activity, dan assessment. Topic yang digunakan menggunakan kalimat bahasa Inggris yang dapat mencakup keseluruhan bahasan, seperti what is the email about? dan How do I operate this?. Description berisi penjelasan tentang topik yang mencakup tujuan dari pembelajaran, tata bahasa serta kosakata yang diajarkan pada unit tersebut. Pada bagian Warm-up terdapat gambar, link video, link rekaman suara, kata atau kalimat yang digunakan sebagai bahasan awal sebelum memulai pembelajaran. Introduction memuat gambar, video, rekaman suara atau kata yang digunakan sebagai diskusi awal pembelajaran menuju topik bahasan. Pada bagian presentation terdapat gambar atau kata yang digunakan untuk mepresentasikan pokok bahasan. Bagian activity memuat kegiatankegiatan atau latihan yang dapat dilakukan agar mahasiswa lebih memahami topik. Sedangkan pada bagian assessment terdapat soal atau instruksi kerja yang digunakan untuk menilai pemahaman siswa terhadap topik yang diajarkan.

Melalui kuesioner yang diberikan kepada mahasiswa, diketahui bahwa bahan ajar yang diberikan menarik bagi mahasiswa, disetujui dapat membantu mencapai tujuan pembelajaran, sangat relevan dengan tujuan pembelajaran, disetujui untuk diterapkan dan disetujui bahwa materi yang diberikan memang dibutuhkan di dunia kerja. Dari hasil penilaian ahli yang mencakup kecermatan isi (valid dan mutakhir), ketepatan cakupan isi (sesuai dnegan tujuan pembelajaran), ketercernaan(logis, runut, terdapat contoh/ilustrasi, serta format konsisten), penggunaan bahasa (kalimat efektif, lugas dan komunikatif), perwajahan (gambar atau kalimat pas), ilustrasi (menarik dan komunikatif) dan kelengkapan komponen (uraian, latihan, umpan balik dan penguatan) menunjukkan niai yang bagus.

\subsection{Pembahasan}

Produk yang dikembangkan ini mengacu pada ADDIE yang mencakup analysis, design, development, implementation dan evaluation. Berikut tahapan pengembangan bahan ajar tersebut.

\section{Analysis}

Pada tahapan ini, peneliti mendeskripsikan apa yang akan dipelajari oleh pembelajaran. Materi yang akan dipelajari diperoleh berdasarkan hasil wawancara dan kuesioner yang sebelumnya sudah disebarkan kepada alumni yang sudah bekerja dan pengguna lulusan. Terdapat empat kemampuan berbahasa yang menjadi fokus, yaitu membaca, mendengar, menulis dan berbicara. Berdasarkan hasil wawancara dan kuesioner, kemudian dipilih beberapa materi yang akan dipelajari yang cocok untuk diberikan kepada mahasiswa semester awal program studi Teknologi Informasi yang meliputi bagian-bagian email, penggunaan present tense, penggunaan present perfect tense, giving suggestion, making request, imperative sentence, replying to enquiries/ request, the use of adjective, offering product, apology dan handling complaint. Pemilihan ini didasarkan pada tingkat kesulitan dari penguasaan materi meningat bahasa Inggris dipelajari mahasiswa lebih dari 1 semester.

\section{Design}

Tahapan ini mencakup perumusan tujuan pembelajaran, strategi pembelajaran, sumber belajar, tes serta desain faktor pendukung proses pembelajaran.

Tujuan pembelajaran adalah kemampuan pembelajar dalam membaca, mendengarkan, menulis dan berbicara bahasa Inggris dengan rincian sebagai berikut.

1. Kemampuan untuk memahami email

2. Kemampuan utnuk memahami procedure text

3. Kemampuan untuk menulis balasan email

4. Kemampuan untuk menulis sebuah deskripsi produk 
5. Kemampuan untuk mendengarkan percakapan bahasa Inggris mengenai deskripsi produk

6. Kemampuan untuk mendengarkan dan memahami keluhan pelanggan

7. Kemampuan untuk mendeskripsikan produk

8. Kemampuan untuk menangani keluhan pelanggan

Pendekatan komunikatif menjadi pilihan peneliti dalam merumuskan bahan ajar bahasa Inggris. Pendekatan ini lebih menekankan pada kemampuan komunikasi pembelajar. Diharapkan motivasi dan kelancaran komunikasi pembelajar menjadi meningkat. Dibandingkan dnegan struktur bahasa, pendekatan ini lebih menekankan kepada fungsi bahasa itu sendiri. Terdapat beberapa jenis sumber belajar yang digunakan yaitu sumber belajar cetak dalam bentuk lembar kegiatan dan gambar, sumber belajar non cetak dalam bentuk video dan rekaman suara, serta sumber belajar dalam bentuk kegiatan berupa wawancara dan diskusi. Tes yang diberikan dalam proses pembelajaran disesuaikan dengan tujuan dari pembelajaran itu sendiri. Tes yang diberikan ada yang dikerjakan secara individu, berpasangan maupun kelompok.

Dalam penerapan proses pembelajaran ini, peran pengajar sangat diperlukan untk menciptakan adanya komunikasi dengan pembelajar ataupun antar pembelajar. Peguasaan teknologi juga menjadi faktor penting untuk mencapai tujuan dari pembealajaran yang diharapkan. Kemutakhiran materi juga menjadi pertimbangan agar pokok bahasana diminati mahasiswa.

\section{Development}

Pada tahapan ini, design dikembangkan hingga menjadi sebuah bahan ajar. Lesson plan dibuat untuk menjadi acuan dalam penggunaan materi yang diberikan. Masing-maisng lesson plan berisi informasi mengenai topik pembelajaran, waktu yang dibutuhkan, kemampuan bahasa yang ditargetkan, tujuan pembelajaran, tata bahasa yang dipelajari, ungkapan atau kalimat bahasa Inggris yang dipelajari, kosakata yang dipelajari, materi yang dibutuhkan, serta prosedur menggunakan materi dalam proses pembealajran. Dalam prosedur, kegiatan yang dilakuakn oleh dosen dan mahasiswa juga dijelasakan lengkap dengan lama waktu yang dibutuhkan serta materi atau bahan yang diperlukan untuk setiap langkah kegiatan. Tahapan kegiatan terdiri dari warm-up, introduction, presentation, activity dan assessment. Warm-up adalah kegiatan awal yang bertujuan untuk menarik perhatian mahasiswa sehingga pikiran mereka akan fokus dan mengarah kepada materi yang akan disampaiakan. Dalam tahapan ini, permainan diberikan kepada mahasiswa seperti permainan menebak kata, menyususn kata, atau melengkapi kata yang kosong. Pada tahapan Introduction, dosen mulai mengenalkan materi yang akan mereka pelajari pada pertemuan tersebut. Cara pengenalannya dapat berupa presentasi langsung, gambar, video, bacaan ataupun rekaman suara. Selanjutnya pada bagian activity, mahasiswa diberikan kegiatan untuk melatih kemampuan mereka untuk mencapai tujuan pembelajaran. Kegaitan yang dilakukan bermcam-macam disesuaikan dengan topik yang sedang dipelajari. Kegiatan yang dilakukan bevariasi mulai dari kegitatan individu, berpasangan hingga berkelompok. Terkahir adalah assessment. Pada bagian ini, dosen melakukan penilaian sejauh mana mahasiswa menguasai materi yang diberikan.

\section{Implementation}

Tahapan ini adalah tahap untuk mengimplementasikan materi yang sudah didesain. Implementasi dilakukan dengan cara mempraktikkannya kepada mahasiswa. Mahasiswa tersebut adalah mahasiswa yang tergabung dalam UKM Bahasa Inggris yang berjumlah 18 orang. Dalam pelaksanaannya, dibutuhkan waktu empat kali pertemuan dengan masing-masing pertemuan mengambil satu kemampuan bahasa yang menjadi fokus. Dalam setiap kali pertemuan, waktu yang dihabiskan adalah kurnag lebih 2 jam. Di awal, dosen menyapa mahasiswa dan memberitahukan tujuan dari implementasi ini. Kemudian dosen mulai untuk melaksanakan kegiatan berdasarkan lesson plan dan materi yang telah disiapkan. Setelah pembelajaran selesai, selanjutnya mahasiswa diberikan daftar pertanyaan dalam bentuk kuesioner terkait proses pembelajaran guna mendapatkan masukan. 


\section{Evaluation}

Setelah implementasi selesai dilaksanakan, selanjutnya adalah tahapan evaluasi. Evaluasi dilakukan dengan berpedaoman pada hasil kuesioner yang diberikan kepada mahasiswa serta koordinator dosen bahasa Inggris di STMIK STIKOM Indonesia. Adapun pertanyaan yang diajukan kepada mahasiswa adalah terkait menariknya materi, keseuaian dengan tujuan pembelajaran, kesesuaian tugas dan latihan yang diberikan, kebermanfaatan materi, serta persetujuan untuk dipergunakannya materi tersebut kedepannya. Sebagian besar mahasiswa memberikan respon yang positif terkait pertanyaan yang diajukan.

Untuk review dari dosen, beberapa variabel diajukan yaitu tentang kecermatan isi, ketepatan cakupan isi, ketercernaan, penggunaan bahasa, perwajahan, ilustrasi serta kelengkapan dokumen. Hampir seluruhnya mendapatkan respon yang positif kecuali terdapat masukan pada runtutan kegiatan untuk pembelajaran speaking dan listening.

\section{KESIMPULAN}

Dari segi kecermatan isi, ketepatan cakupan isi, ketercernaan, penggunaan bahasa, perwajahan, ilustrasi serta kelengkapan dokumen, bahan ajar Bahasa Ingris yang dikembangkan sudah layak dan siap untuk diimplementasikan nantinya. Akan tetapi berdasarkan masukan yang diberikan, revisi tetap perlu untuk dilakukan, terutama dalam aspek runtutan kegiatan demi bahan ajar yang lebih baik.

Adapun saran yang dapat diberikan penulis sebagai berikut.

1. Hendaknya bahan ajar yang digunakan dalam pembelajaran mengaju pada analisis kebutuhan mahasiswa nantinya di dunia kerja

2. Pengembangan bahan ajar hendaknya dilakukan secara periodik mengingat perkembangan zamn dan teknologi yang tentunya mempengaruhi kebutuhan kompetensi lulusan di dunia kerja

\section{UCAPAN TERIMA KASIH}

Penelitian ini dapat berjalan karena dukungan dari berbagai pihak. Pada kesempatan ini penulis ingin menyampaikan ucapan terima kasih kepada STMIK STIKOM Indonesia yang telah membantu penulis dalam memberikan dana penelitian. Tidak lupa penulis ingin mengucapkan rasa terima kasih pada Dosen dan mahasiswa STMIK STIKOM Indonesia atas kerjasama dan dukungannya sehingga penyusunan bahan ajara dan laporan penelitian ini dapat diselesaikan dengan baik.

\section{DAFTAR PUSTAKA}

Aisyah, Siti; Noviyanti, E., \& Triyanto. (2020). BAHAN AJAR SEBAGAI BAGIAN DALAM KAJIAN PROBLEMATIKA PEMBELAJARAN. Salaka, 2(1), 62-65.

Branch, R. M. (2009). Instructional Design-The ADDIE Approach. Springer.

Chomsin, W. S., \& Jasmadi. (2008). Panduan menyusun bahan ajar berbasis kompetensi. PT Elex Media Komputindo.

Dewi, N. K. H. P. (2019). Tantangan Mengeleminir Sarjana Menganggur. Balipost. https://www.balipost.com/news/2019/10/11/89651/Tantangan-Mengeleminir-SarjanaMengganggur.html

Hakim, M. Arif Rahman; Kurniawan, Yuda Septian; Saputra, A. (2019). PENGEMBANGAN MODUL PENGAJARAN BAHASA INGGRIS UNTUK PROGRAM STUDI EKONOMI SYARIAH BERBASIS CONTEXTUAL TEACHING LEARNING (CTL). Jurnal Aghinya Stiesnu Bengkulu, 2(1), 11-24.

Idris, M. (2018). Menaker Ingatkan Pekerja Pentingnya Lancar Berbahasa Inggris. Detiknews. https://news.detik.com/berita/d-4240335/menaker-ingatkan-pekerja-pentingnya-lancar- 
berbahasa-inggris

Ihsan, D. (2020). Mendikbud: Soft Skill dan Hard Skill Sama Pentingnya. Kompas.Com. https://www.kompas.com/edu/read/2020/12/08/205635971/mendikbud-soft-skill-danhard-skill-sama-pentingnya

Lestari, W., Pendidikan, A., \& Palembang, U. M. (2021). Pengembangan Modul Pembelajaran Bahasa Inggris Berbasis Andragogi Pada Program Studi Pendidikan Biologi di Universitas Muhammadiyah Palembang A . Pendahuluan strategi pembelajaran yang harus diarahkan pada keefektifan mahasiswa, sedangkan pembelajaran ES. Edunesia: Jurnal Ilmiah Pendidikan, 2(1), 171-177.

Mudofir, I. (2016). Pentingnya Pengembangan Bahan Ajar Bahasa Inggris Berbasis Multimedia. Kemampuan Koneksi Matematis (Tinjauan Terhadap Pendekatan Pembelajaran Savi), $6(1), 62-74$.

Prastowo, A. (2011). Metode Penelitian Kualitatif dalam Perspektif Rancangan Penelitian. Ar-Ruzz Media.

Purwanto, P. P. (2001). Penulisan Bahan Ajar. Pusat antar universitas untuk peningkatan dan pengembanganaktivitas intruktional Ditjen Dikti Diknas.

Sugiyono. (2015). Metode Penelitian Kombinasi (Mix Methods). 